\title{
KROCK MELLAN REPRESENTATIV DEMOKRATI OCH PARTIDEMOKRATI
}

\author{
Magnus Hagevi, Institutionen för statsvetenskap, Linnéuniversitetet \\ E-post I magnus.hagevi@lnu.se
}

I samhällsvetenskap brukar forskare undvika att formulera allmängiltiga lagar, utan talar hellre om tendenser. Men John May (1973) har formulerat en relation som blivit kallad för Mays lag. Enligt denna lag är de aktiva gräsrötterna i politiska partier engagerade av ideologisk övertygelse. Men när partierna går till val vill de som kandiderar i valen fånga så många av väljarnas röster som möjligt. Väljarna tenderar att vara mindre engagerade och mindre ideologiskt övertygade än partiernas medlemmar. För att maximera röstetalet anpassar sig partierna och deras kandidater så att de liknar väljarna mer och partiets egna gräsrötter mindre. Det innebär att partiernas medlemmar tenderar att vara mer ideologiskt extrema än vad som är fallet med ett partis väljare och dess valda politiker. I föreliggande studie är avsikten att analysera i vad mån Mays lag är giltig i svensk politik.

Med sin lag sätter May fingret på något som skaver mellan intern partidemokrati och en stats representativa demokrati. Representativ demokrati och partidemokrati är två olika normativa ideal. Den representativa demokratin betonar att det demokratiska valet ska resultera i att medborgarna blir representerade av de valda politikerna. Vid sidan av 
ansvarighet betonas att de valda politikernas åsikter ska överensstämma med väljarnas, så kallad åsiktsrepresentativitet. ${ }^{1}$ Idealet med åsiktsöverensstämmelse mellan väljare och valda sammanfattades kärnfullt av den svenska representationsforskningens pionjär, statsvetarprofessorn Jörgen Westerståhl:

De valda ska vara åsiktsrepresentativa för sina väljare och genom denna åsiktsrepresentativitet skall folkstyrelsens övergripande mål, folkviljans förverkligande, främjas. (Westerståhl \& Johansson 1981:20).

Men partierna kan ha anammat en annat normativt ideal i form av masspartier (Duverger 1954). Dessa kännetecknas av att vara öppna medlemsorganisationer med väl utvecklad interndemokrati där alla partimedlemmar har lika mycket makt. Enligt masspartiets ideal är det medlemmarna tillsammans som bestämmer partiets substantiella politik, som de partirepresentanter som råkar bli valda i beslutande församlingar sedan har att effektuera. Masspartierna avser också att representera bestämda grupper bland väljarna, vilket är partiernas sociala baser. Det är från dessa sociala baser masspartiernas medlemmar rekryteras och det är från de sociala baserna som masspartiernas röster kommer vid valen. Därmed antas skillnaderna mellan väljare, medlemmar och valda vara små, i alla fall vad gäller politiska åsikter.

Så länge partiernas medlemmar och väljare har samma åsikter finns inga problem mellan de normativa idealen för representativ demokrati och för masspartiet. Men problemen uppkommer om väljare, partimedlemmar och valda politiker skiljer sig åt vad gäller intressen, erfarenheter och politiska åsikter. Det kan då bli en krock mellan vad de valda politikerna ska företräda: väljarna eller partimedlemmarna? I denna artikel är avsikten att granska den åsiktsmässiga överensstämmelsen i Sverige mellan partiernas väljare, partimedlemmar och riksdagsledamöter 2010 och jämföra med tiden innan det stora tappet av partimedlemmar började på 1980-talet. Dessutom analyseras motsvarande problematik utifrån förekomsten av det tvåblocksystem som kampen mellan Alliansen och De rödgröna har resulterat i.

\section{Teori}

Politiska partier har en central roll i representativ demokrati. Det är partierna som utvecklar politiska program, rekryterar kandidater som kan väljas till politiska poster och samlar väljarnas röster. Partiernas betydelse är speciellt stor i politiska system som liknar det svenska där den politiska representationen väljs i proportionella val och regeringen utses enligt parlamentarismens principer. I proportionella val av svensk typ är det i första hand partier som väljarna röstar på (Oscarsson \& Holmberg 2013). Det är partierna som erhåller rösterna och det är partiernas andel mandat i riksdagen som ska vara proportionellt fördelade med väljarnas röster på partierna (Farell 2011). När valet 
väl är över är det partier med stor sammanhållning (Fransson 2010) som är riksdagens huvudaktörer (Hagevi 2000). Utan sammanhållna partier blir det svårt för en regering att föra politik. Partier som fragmenteras riskerar att förlora väljarnas förtroende och straffas i nästkommande val. På detta sätt - genom en parlamentarisk ansvarskedja - är det partierna som länkar medborgarna till makthavarna och de politiska besluten (Strøm \& Bergman 2011).

Partiernas starka roll i svensk politik innebär att det i mycket är dessa som representerar väljarna. I stort sett alla valda politiker representerar i första hand sitt parti (Hagevi 1998). Tanken om åsiktsrepresentation blir därmed en åsiktsöverensstämmelse mellan väljarna och de politiker som tillhör det parti som väljarna röstat på (Holmberg 1974). Det är lätt att tänka sig att representationen är som bäst när den åsiktsmässiga överensstämmelsen mellan väljare och valda är som störst. En invändning är dock att politisk representation inte enbart innebär att ha samma åsikt som sin uppdragsgivare (även kallad principal). Som ombud (även kallad agent) för väljarna har bland annat Hanna Pitkin (1967) argumenterat för att representation är mer än att bara åsiktsrepresentation. Ett ombud ska representera sina uppdragsgivare (väljarna) genom att agera i enlighet med vederbörandes intressen. Själva tanken med representation är att ombuden, riksdagsledamöterna, ska bli experter och ha bättre kunskaper än vad som är vanligt bland väljare. Därför är det inte orimligt att riksdagsledamöterna, i kraft av sin expertis, ibland har en annan åsikt än de som röstat på partiet. Istället för att agera blint enligt väljarnas önskningar kan de, menar Pitkin, agera som goda representanter genom att fatta de beslut som är i väljarnas intressen och som väljarna också skulle ha beslutat om de haft samma information som riksdagsledamöterna. Men, påpekar Pitkin, det är viktigt att representanterna kan övertyga väljarna om att besluten är i deras intressen. Bristande åsiktsöverensstämmelse mellan väljare och valda får därför inte vara för evigt eller bli allt för omfattande. Annars fungerar inte längre representationen.

Något som komplicerar representationen är förekomsten av partidemokrati. Det kan sägas vara en del av en så kallad mellanvalsdemokrati där medborgare (dit partimedlemmar får räknas) "har möjlighet att påverka politiken på andra sätt än genom att rösta fram politiska representanter i val” (Brothén \& Gilljam 2006:194). Problemet med mellanvalsdemokrati är att medborgare som visar detta politiska engagemang - till exempel aktiva partimedlemmar - kan ha andra åsikter än resten av väljarna. Vem ska då riksdagsledamöterna representera: väljarna eller partimedlemmarna? Flera statsvetare menar att detta inte bara är en hypotetisk risk, utan så reell att partidemokrati och representativ demokrati har dömts ut som inkompatibla (McKenzie 1982). May (1973) har, som nämndes i artikelns inledning, preciserat dessa risker i vad som kallats för Mays lag om kurvlinjära opinionsstrukturer inom politiska partier (se tabell 1). 
Tabell 1: Mays lag.

\begin{tabular}{|c|c|c|c|c|}
\hline Nivå & Består av & Motiv & Strategi & Åsikter \\
\hline Partielit & $\begin{array}{l}\text { Politiker som } \\
\text { vunnit position } \\
\text { genom allmänna } \\
\text { val (t ex riksdags- } \\
\text { ledamöter }\end{array}$ & $\begin{array}{l}\text { Rationella aktörer } \\
\text { som vill vinna val, } \\
\text { bli omvalda och } \\
\text { röstmaximera }\end{array}$ & $\begin{array}{l}\text { Partieliten vill vara } \\
\text { nära sina potentiella } \\
\text { väljare och antar } \\
\text { modererande } \\
\text { ståndpunkter }\end{array}$ & Modererande \\
\hline Gräsrötter & Partimedlemmar & $\begin{array}{l}\text { Ideellt arbetande } \\
\text { medlemmar som } \\
\text { drivs av ideologisk } \\
\text { övertygelse }\end{array}$ & $\begin{array}{l}\text { Vill förverkliga sin } \\
\text { ideologiska överty- } \\
\text { gelse i politiken på } \\
\text { lång sikt och får litet } \\
\text { ut av att eliten blir } \\
\text { omvald, varför deras } \\
\text { ideologiska överty- } \\
\text { gelse inte modereras }\end{array}$ & Extrem \\
\hline Väljare & $\begin{array}{l}\text { Potentiella väljare } \\
\text { som ibland röstar } \\
\text { på partiet }\end{array}$ & $\begin{array}{l}\text { Väljarna antas } \\
\text { stödja partier vars } \\
\text { ståndpunkter upp- } \\
\text { fattas stå nära deras } \\
\text { egna åsikter }\end{array}$ & $\begin{array}{l}\text { De flesta väljare drivs } \\
\text { inte av ideologisk } \\
\text { övertygelse utan av } \\
\text { partiernas vallöften }\end{array}$ & Modererande \\
\hline
\end{tabular}

Till att börja med kommenterar jag tredje och sista raden i tabell 1. Där beskrivs väljarna, eller snarare de väljare som kan tänka sig att rösta på ett parti. De antas stödja partier vars ståndpunkter bäst överensstämmer med väljarnas egna åsikter (Downs 1957). De flesta väljarna drivs, enligt May, inte av ideologisk övertygelse, i alla fall inte på samma sätt som politiskt aktiva gör, utan av partiernas vallöften i vid mening. Därmed tenderar inte väljarna att anta några ideologiska extremåsikter, utan vara ideologiskt måttliga.

Låt oss nu gå till den översta raden i tabell 1. Enligt May kommer vad som kan kallas för partieliten - politiker som vunnit position genom allmänna val - att drivas av andra intressen än gräsrötterna i partiet (Michels 1983). Partieliten har ofta politik som yrke och som politikerproffs strävar de först och främst att bli omvalda. Därmed vill partieliten samla så många röster som möjligt - röstmaximera (Downs 1957). På så sätt säkerställer partieliten sina positioner, får så stort inflytande som möjligt och - som i ett partisystem som det svenska - bättre ekonomiska förutsättningar i form av statligt partistöd (eftersom detta, för riksdagspartier, är knutet till antal mandat i riksdagen). Utifrån tanken att väljarna röstar på det parti vars åsikter bäst överensstämmer med de egna (Downs 1957) bör partieliten inta ståndpunkter som de uppfattar vara så nära deras potentiella väljare som möjligt. 
Eftersom väljarna, enligt May, har ideologiskt måttliga åsikter antar han att partieliten modererar sina åsikter så att de inte uppfattas som för extrema. Dessutom kan partierna nominera kandidater till val utifrån uppfattningen att deras åsikter är mer i samklang med väljarna.

Figur 1: Teoretiskt utfall av Mays lag.

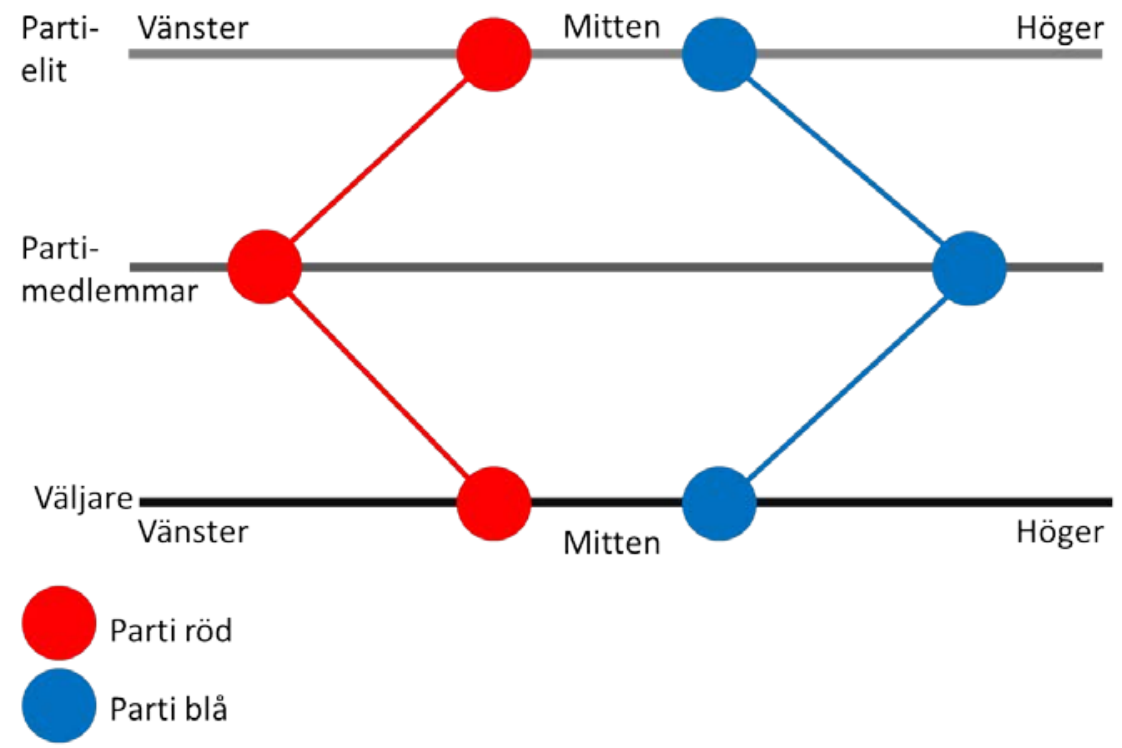

I andra raden i tabell 1 beskrivs vad som driver partimedlemmarna i deras engagemang. Till skillnad från partieliten har de sällan, och i så fall små och tämligen obetydliga, positioner som valda politiker. De har inte investerat $\mathrm{i}$ en politisk yrkeskarriär och har inte mycket att förlora på att bli bortröstade av väljarna. Istället tenderar partimedlemmarna, speciellt de som är aktiva i partiet, att vara ideologiskt övertygade idealister. För dem är det inte så stor skillnad om deras övertygelse röstas bort eller överges av partieliten för att erhålla maximalt antal röster till partiet. Då detta mellanskikt strävar efter att förverkliga sin ideologiska övertygelse på lång sikt tycker de att det inte är så viktigt om partieliten blir omvald eller inte. Därför modererar de inte sina ställningstaganden utan är mer ideologiskt extrema än både väljarna och partieliten.

Låt oss summera: väljarna och partieliten uppvisar åsikter som är ideologiskt moderata, medan partiets gräsrötter, mellanskiktet, är ideologiskt extrema. Om vi tänker oss två partier som placerar sig på en vänster-högerskala borde väljarna och partieliten placera sig närmare mitten på skalan, medan partiets gräsrötter är mer extrema. För ett parti åt vänster innebär det att gräsrötterna är längre åt vänster än partiets elit och väljare, medan för ett parti åt höger att gräsrötterna är mer åt höger än partiets elit och väljare. Förhållandet åskådliggörs i figur 1 . 
Enligt Mays lag ska således medlemmar i partier som är till vänster i politiken vara längre åt vänster än såväl eliten i, som väljarna till, deras parti. Däremot ska medlemmar i partier som är till höger i politiken vara längre åt höger än såväl eliten i, som väljarna till, deras parti.

Sedan May formulerade sin lag menar många forskare att partierna har förändrats. Partimedlemmarnas betydelse minskar. För de stora riksdagspartierna är den största inkomstkällan partistöd från stat, landsting och kommun, inte från medlemsavgifter. Partieliten antas handla mer och mer självständigt gentemot partimedlemmarna (Katz \& Mair 1995, 2009). Också antalet partimedlemmar har blivit mindre. Det betyder att andelen partimedlemmar som dessutom har ett offentligt förtroendeuppdrag - som resultat av valresultatet - har blivit större i partierna. Genom att en större andel av partimedlemmarna också är beroende av valresultatet för sin politiska aktivitet kanske också skillnaden mellan att vara partimedlem och partielit minskar. Därmed kan Mays lag vara något som gällde förr, men inte nu.

Till detta kommer att de svenska partierna i allt större utsträckning kopplas till ett av två politiska block: Allianens och De rödgröna. Frågan som infinner sig är om Mays lag fungerar om den appliceras på de två politiska blocken. Förvisso är det (ännu) inte möjligt att lösa medlemskap i ett politiskt block. Men i respektive parti som ingår i ett block finns det medlemmar som tillsammans bildar mellanskiktet med gräsrötter i respektive block. Men är detta mellanskikt mer ideologiskt extremt än respektive blocks väljare och partielit? I denna artikel är avsikten att besvara tre frågeställningar.

1. Var partimedlemmarna mer extrema än respektive partis riksdagsledamöter och väljare vid riksdagsvalet 2010?

2. Stämde Mays lag bättre innan andelen medborgare som var partimedlemmar minskade jämfört med partierna av idag?

3. Är medlemmarna i de partier som ingår i Alliansen och De rödgröna mer extrema än respektive blocks riksdagsledamöter och väljare?

\section{Tidigare forskning}

Herbert Kitschelt (1989) fann att Mays lag överlag inte överensstämde med förhållandena i ett par belgiska ekologiska partier i mitten av 1980-talet (i alla fall i den tappning av lagen som May statuerade). I sin undersökning av brittiska Conservatives och Labour i början av 1990-talet visade Pippa Norris (1995) på ett än mindre stöd för Mays lag. Partiaktivisterna var inte mer radikala än sina parlamentariska företrädare. Bland Conservatives var det just parlamentarikerna som, istället för att verka 
modererande, var mest extrema. Inom Labour fanns ingen egentlig skillnad mellan väljare, partiaktivister och parlamentariska representanter. Norris förklarar den bristande överensstämmelsen med Mays lag med att politiker som är villiga att möta motståndarna inför väljarna måste betala en omfattande kostnad och ta stora risker på vägen dit. Detta kan de bara klara av genom att vara övertygade anhängare av sitt parti. Om de lyckas med sin politiska karriär förstärker snarare en försvagar de politiska debatterna i parlament, massmedia och bland väljare deras engagemang för sitt partis ideologi.

Statsvetaren Anders Widfeldt (1999) har undersökt i vad mån Mays lag kunde appliceras på Socialdemokraterna, Moderaterna och Centerpartiet åren 1985, 1988 och 1994. Övriga riksdagspartier studerade han inte. Widfeldt menar att det finns ett visst, men inte entydigt stöd, för Mays lag. I två tredjedelar av de nio undersökta fallen fann han att Mays lag fick stöd. Vad gäller Socialdemokraterna fick Mays lag alltid stöd, medan den fick svagast stöd när Moderaterna studerades (ett mättillfälle, 1988, av tre). För Centerpartiet uppgav Widfeldt att Mays lag fick stöd vid två mättillfällen (1985 och 1988).

I mitten av 00-talet studerade statsvetaren Svend Dahl (2011) Mays lag utifrån tanken att partiaktivister skulle göra andra prioriteringar än partisekreterare och partiombudsmän. Han menade att de sistnämnda två, speciellt partisekreterarna, skulle vara mer strategiskt orienterade än partiaktivisterna som istället antogs vara mer ideologiskt drivna. På grundval av kvalitativa intervjuer bland moderater, socialdemokrater och centerpartister kunde Dahl inte upptäcka någon sådan skillnad mellan dessa grupper. Det finns problem med att dra generella slutsatser utifrån intervjustudier som inte är baserade på representativa urval. Förvisso är det rimligt att betrakta partisekreterare som en del av partiledningen, men det är också problematiskt att samtliga intervjuade var aktörer inom partiorganisationerna och inte valda politiker.

Någon undersökning som beaktar samtliga svenska riksdagspartier och som jämför väljare, partimedlemmar och valda har, mig veterligen, inte genomförts.

\section{Data och mätinstrument}

Vad gäller väljarnas åsikter används Survey 2010 och för partimedlemmar används Survey 2009, 2010 och 2012 (Hagevi 2014). Anledningen till att tre undersökningar används för partimedlemmar är att få så många svarandre partimedlemmar i respektive parti som möjligt. Detta ökar säkerheten i resultaten. Partieliterna representeras av riksdagsledamöter som undersöks vid två tillfällen: 1985 och 2010 genom Riksdagsenkät 1985 och 2010 som genomförts vid Statsvetenskapliga institutionen, Göteborgs universitet (Esaiasson \& Holmberg 1985; Esaiasson m fl 2010). För att 
undersöka väljare och partimedlemmar 1985 används data från Väljarundersökningen 1985 som genomförts på Göteborgs universitet (Holmberg \& Gilljam 1987).

Survey 2010 och Väljarundersökningen 1985 genomfördes i samband med riksdagsvalen respektive år.

För att undersöka åsiktsöverensstämmelsen mellan väljare, partimedlemmar och partielit kommer jag att använda en 11-gradig vänster-högerskala som går från 0 (”Långt till vänster”) till 10 (”Långt till höger”). ${ }^{2}$ I Surveyinstitutets undersökning är därtill 5 markerat med "Mitten”. Svarspersonerna till Survey 2009, 2010 och 2012 har ombetts att placera sig själva på denna vänster-högerskala genom att sätta ett kryss i rutan som ligger närmast deras placering (se figur 2). Det är även möjligt att ange "vet ej” för den som inte vet sin placering på vänster-högerskalan.

\section{Figur 2: Subjektiv vänster-högerskala i Survey 2009, 2010 och 2012.}

Man talar ibland om att politiska åsikter kan placeras in på en vänster-högerskala. Var skulle du placera in dig själv på en sådan vänster-högerskala? Kryssa i den ruta som ligger närmast din placering.

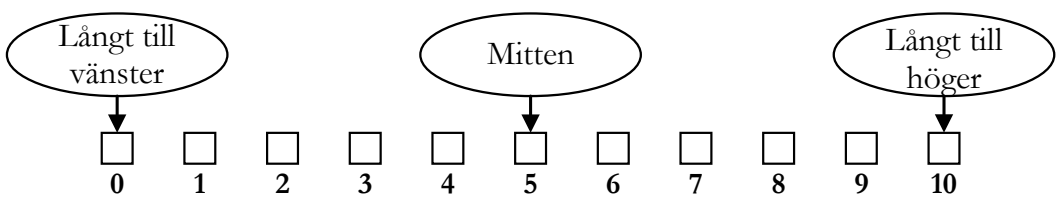

Skalan i figur 2 är den subjektiva vänster-högerskala som används i Survey 2009, 2010 och 2012. Det betyder att det är helt och hållet svarspersonen, subjektet, som bestämmer vad som avses med vänster, höger och mitten samt tolkar talen på skalan. I svensk politik är det dock vanligt att väljarnas placering på vänster-högerskalan är starkast kopplat till ekonomisk politik som i stor utsträckning rör åsikt om statens roll i ekonomin. Det finns dock klara tendenser som visar att andra värderingar om till exempel normer och miljö i allt större omfattning har samband med vänster-högerskalan (Hagevi 2011).

I Riksdagsenkäterna 1985 och 2010 samt Väljarundersökningarna 1985 används en något annorlunda mätmetod av svarspersonernas placering på vänster-högerskalan. Även nu är det en 11-gradig vänster-högerskala, men värde 5 är markerat med "varken till vänster eller till höger" och någon möjlighet att uppge "vet ej” finns inte. Bedömningen är ändå att dessa båda 11-gradiga skalor är relativt lika varandra och de skillnader som emanerar ur olika mätmetoder är mycket små. 


\section{Mays lag 2010}

Låt oss först undersöka stödet för Mays lag 2010. I figur 3 redovisas medelvärdet för placeringen på vänster-högerskalan för respektive partis väljare, medlemmar och riksdagsledamöter 2010. Den nedre linjen visar väljarnas placering på vänsterhögerskalan.

Partimedlemmarnas placering på vänster-högerskalan visas på den mellersta linjen. Den översta linjen redovisar placeringen för partiernas riksdagsledamöter (som representanter för partieliten). Mays lag får stöd om partimedlemmarna är mer extrema än respektive partis riksdagsledamöter och väljare.

Figur 3: Mays lag 2010 (medelvärden).

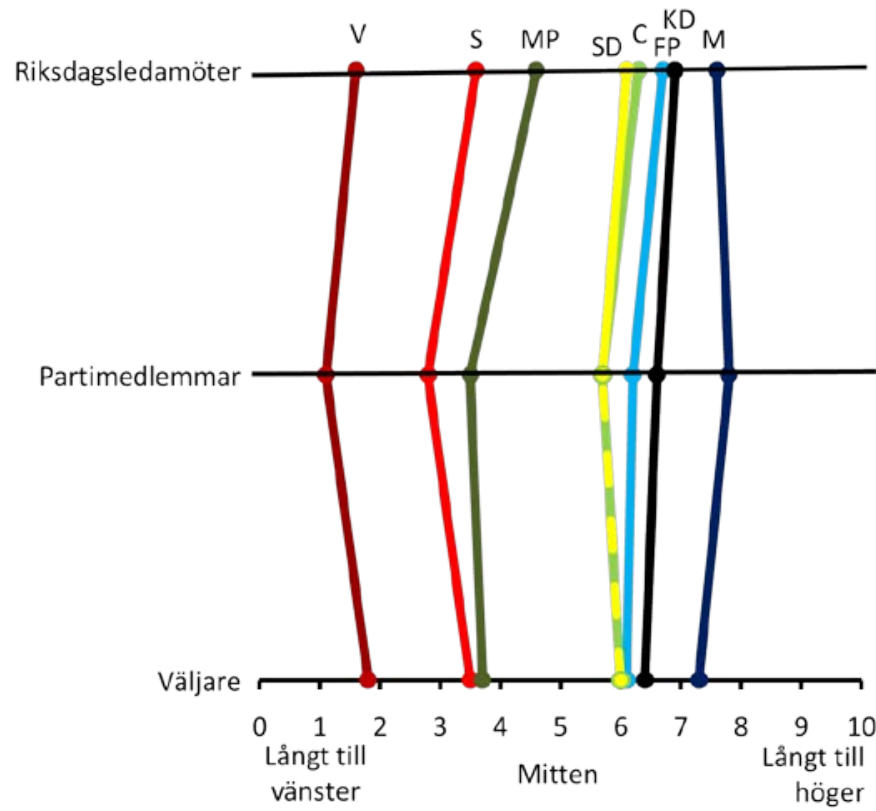

Kommentar: Data om väljare från Survey 2010, data om partimedlemmar från Survey 2009, 2010, 2012 (samtliga Surveyinsitutet, Linnéuniversitetet) och data om riksdagsledamöter från Riksdagsenkät 2010 (Göteborgs universitet).

För vissa partier ger resultatet ett visst stöd för Mays lag, medan för andra partier avviker mönstret från vad Mays lag stipulerar. För partierna till vänster om mitten Vänsterpartiet, Socialdemokraterna och Miljöpartiet - ter sig Mays lag tillämplig. Samma sak gäller Moderaterna, partiet längst till höger. För alla dessa partier placerar sig partimedlemmarna mer extremt än vad som är fallet för partiernas väljare och elit. För Vänsterpartiet, Socialdemokraterna och Miljöpartiet innebär det att partimedlemmarna är till vänster om väljare och partielit, medan för Moderaterna att partimedlemmarna är till höger om väljare och partielit. 
Däremot följer inte Sverigedemokraternas, Centerpartiets, Folkpartiets och Kristdemokraternas väljare, partimedlemmar och riksdagsledamöter det mönster som kännetecknar Mays lag. Medlemmarna i Folkpartiet och Kristdemokraterna placerar sig mittemellan väljarnas och riksdagsledamöternas genomsnittliga placering på vänsterhögerskalan. Vad gäller Sverigedemokraterna och Centerpartiet placerar sig deras väljare på samma position på vänster-högerskalan. Samma sak gäller dessa båda partiers partimedlemmar. I figur 3 markeras detta med en streckad linje som ömsom är gul, ömsom grön. Sverigedemokraternas och Centerpartiets partimedlemmar ligger närmare mitten än vad som är fallet med partiernas väljare och riksdagsledamöter.

För Centerpartiet går det dock att argumentera för att deras partimedlemmar ska vara "centerextremister” och vilja vara så nära mitten som möjligt. I så fall passar även detta parti in i det mönster som ska bli utfallet enligt Mays lag då Centerpartiets riksdagsledamöter dragit sig närmare sina väljare än partiets medlemmar har gjort.

Nåväl, om May menade att de mer extrema partimedlemmarna skulle vara ett lagbundet mönster så har inte Mays lag fått stöd. En lag ska gälla alla partier, inte bara några. Om vi däremot talar om tendenser i Mays riktning så uppvisar hälften av partierna ett mönster som överensstämmer med Mays lag (och hälften gör det inte), vilket får sägas vara ett mediokert resultat. Men vi kan även ta hänsyn till partiernas storlek. Då är det enbart ett gäng småpartier till höger om mitten som avviker, medan stora partier som Socialdemokraterna och Moderaterna uppvisar ett mönster som överensstämmer med Mays lag. Tillsammans med Miljöpartiet och Vänsterpartiet betyder det att omkring tre fjärdedelar av väljarkåren röstar på partier vars medlemmar är mer ideologiskt extrema än dem själva och partiernas representanter i riksdagen.

\section{Mays lag 1985}

Stämde Mays lag bättre vid tiden innan den dramatiska minskningen av partimedlemmar inleddes jämfört med partierna av idag? I figur 4 redovisas medelvärdet för var partiernas respektive väljare placerar sig på vänster-högerskalan vid riksdagsvalet 1985 (nedre linjen), partiernas medlemmars genomsnittliga placering på samma skala samma år är markerade på mellersta linjen och på den översta linjen finns medelplaceringen för partiernas riksdagsledamöter (som representanter för partieliten) år 1985.

Stödet för Mays lag är inte starkare 1985 jämfört med 2010. Det är alltså inte så att Mays lag stämde bättre överens med förhållanden som rådde innan den stora medlemsnedgången ägde rum för de svenska partierna. Undantaget Centerpartiet och Moderaterna finns inget parti som uppvisar det mönster som Mays lag stipulerar. Istället för att partimedlemmarna placerar sig mer extremt på vänster-högerskalan än väljare 
och riksdagsledamöter framstår det som om partimedlemmarna intar en medlande position mellan väljare och riksdagsledamöter. Detta framgår klarast för Vänsterpartiet och Socialdemokraterna och även till viss del för Folkpartiet. Utifrån dessa data tycks partimedlemmarna mer ta på sig en roll som länk mellan elit och medborgare likt det ideal som representeras av masspartiet.

Figur 4: Mays lag 1985 (medelvärden).

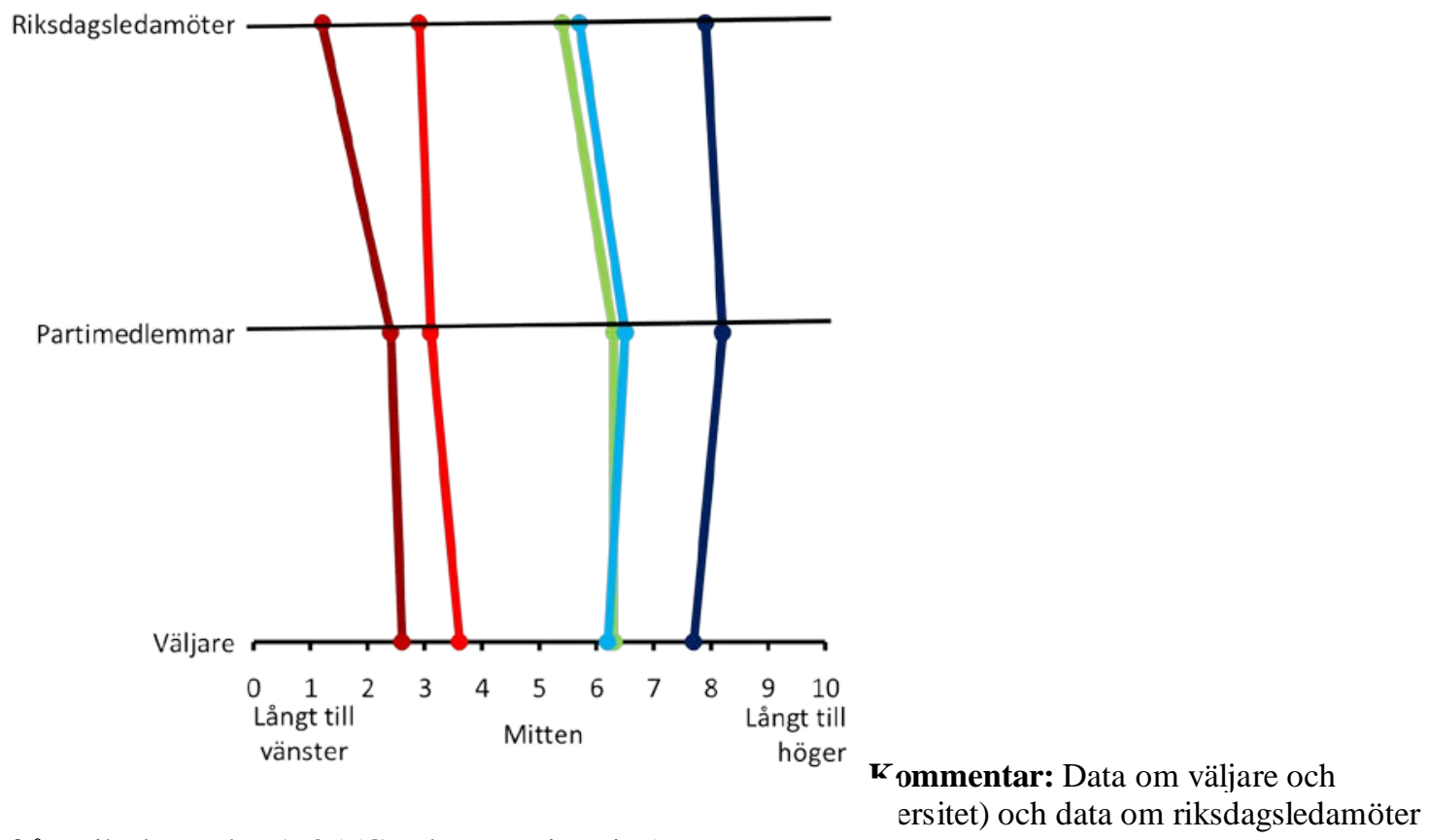

från Riksdagsenkät 1985 (Göteborgs universitet).

Vid en jämförelse mellan resultaten i figur 3 och 4 noteras också förändringar mellan partierna inom de båda politiska blocken. År 1985 är åsiktsavståndet för de borgerliga partierna - de som idag kallas för Alliansen - minst på väljarnivå, något större bland partimedlemmarna och störst bland riksdagsledamöterna. För de partier som senare ingick i De rödgröna är avståndet mellan partierna på vänster-högerskalan minst bland partimedlemmarna, något större bland väljarna och störst bland det gamla socialistiska blockets riksdagsgrupper. Jämfört med 1985 verkar förhållande mellan de politiska blocken vara det omvända 2010. Mays lag är 1985 starkare bland borgerliga partier, 2010 är det bland rödgröna partier. Medlemmarna i de socialistiska partierna står 1985 närmare varandra jämfört med de borgerliga partierna, medan Alliansens partimedlemmar står relativt sett närmare varandra än vad som är fallet bland de rödgröna partierna 2010. 


\section{Mays lag och de politiska blocken}

Den tredje och sista frågeställningen som ska behandlas rör om medlemmarna i de partier som ingår i Alliansen och De rödgröna är mer extrema än respektive blocks riksdagsledamöter och väljare. För att ge ett svar på denna fråga är avsikten att beräkna ett gemensamt medelvärde för Alliansens respektive De rödgrönas väljare, partimedlemmar och riksdagsledamöter på vänster-högerskalan.

När de politiska blockens medlemmar jämförs med riksdagsledamöterna och partiernas väljare märks att graden av valframgång inte alltid är kopplat till antal medlemmar i partierna. Vissa partier har, trots liten medlemsskara, nått ganska stora väljarframgångar, medan partier med en stor medlemsstock inte lyckats lika väl i riksdagsvalen. Eftersom antal riksdagsledamöter är beroende av antalet röster som ett parti får i riksdagsvalen kan det finnas ganska stora skillnader mellan å ena sidan andelen partimedlemmar och, å andra sidan, andelen röster och riksdagsledamöter som ett parti har. I tabell 2 redovisas respektive riksdagspartis andel av samtliga svarande som är medlemmar i ett politiskt parti i Survey 2009-2012.

Tabell 2: Partimedlemmar i riksdagspartierna, 2009-2012 (procent).

\begin{tabular}{|c|c|c|c|}
\hline & Samtliga & Inom respektive block & \\
\hline Moderaterna & 25 & 48 & \\
\hline Centerpartiet & 17 & 32 & \\
\hline Folkpartiet & 6 & 11 & \\
\hline \multirow[t]{2}{*}{ Kristdemokraterna } & 4 & 8 & \\
\hline & & $\sum 99$ & $n=152$ \\
\hline Socialdemokraterna & 33 & 77 & \\
\hline Vänsterpartiet & 6 & 13 & \\
\hline Miljöpartiet & 4 & 9 & \\
\hline Sverigedemokraterna & 4 & $\sum 99$ & $n=127$ \\
\hline Summa procent & 99 & & \\
\hline Antal svarande & 292 & & \\
\hline
\end{tabular}

Kommentar: På grund av avrundning summerar inte antal procent till 100. Data från Survey 2009, 2010 och 2012.

Av tabell 2 framgår att det utifrån antalet partimedlemmar finns tre stora partier i svensk politik: Socialdemokraterna, Moderaterna och Centerpartiet. Totalt är 75 procent av partimedlemmarna med i något av dessa tre partier. Detta skiljer sig från riksdag och väljarkår där det bara finns två stora partier (Socialdemokraterna och Moderaterna). Trots ett relativt litet väljarunderlag och en krympande riksdagsgrupp har således Centerpartiet en ganska stor medlemskader. Övriga partier kan även när det gäller andelen av det totala antalet partimedlemmar betecknas som småpartier. För de båda blockens medelvärde på vänster-högerskalan innebär det att respektive partis 
medlemmar påverkar detta olika mycket. Inom Alliansen påverkar Moderaterna (48 procent av partimedlemmarna i Alliansen) och Centerpartiet (32 procent av partimedlemmarna i Alliansen) ungefär lika mycket var Allianspartimedlemmarna placerar sig på vänster-högerskalan. Däremot inverkar partimedlemmarna från Folkpartiet (11 procent av partimedlemmarna i Alliansen) och Kristdemokraterna (8 procent av partimedlemmarna i Alliansen) inte så mycket var partimedlemmarna från Alliansen gemensamt placerar sig på en vänster-högerskala. För De rödgröna dominerar Socialdemokraternas partimedlemmar ( 77 procent av De rödgrönas partimedlemmar) över partimedlemmarna i Vänsterpartiet (13 procent av De rödgrönas partimedlemmar) och Miljöpartiet (9 procent av De rödgrönas partimedlemmar).

I figur 5 presenteras var väljare som röstat på partierna i Alliansen och De rödgröna placerar sig på vänster-högerskalan vid riksdagsvalet 2010 (nedre linjen), motsvarande medelvärde för var partimedlemmarna kopplade till de båda blocken är markerade på den mellersta linjen och på den översta linjen finns medelplaceringen för blockens riksdagsledamöter (som representanter för partieliten) år 2010.

Figur 5: Mays lag och de politiska blocken 2010 (medelvärden).

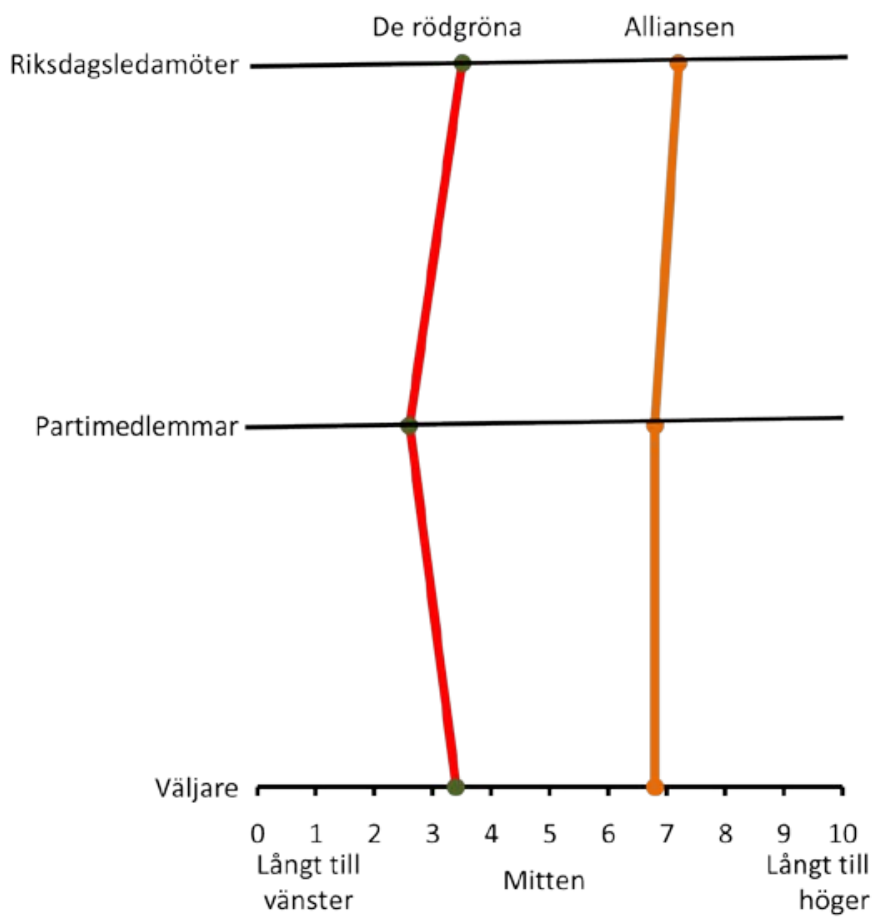

Kommentar: Data om väljare från Survey 2010, data om partimedlemmar från Survey 2009, 2010, 2012 (samtliga Surveyinsitutet, Linnéuniversitetet) och data om riksdagsledamöter från Riksdagsenkät 2010 (Göteborgs universitet). 
För De rödgröna framträder det mönster som Mays lag gör gällande: partimedlemmarna placerar sig mer extremt på vänster-högerskalan (längre till vänster) än vad De rödgrönas väljare och riksdagsledamöter gör. Resultatet är föga överraskande med tanke på att mönstret för samtliga rödgröna partier överensstämmer med Mays lag 2010 (se figur 3) samt att Socialdemokraternas medlemskader dominerar i det rödgröna blocket. Mönstret för Alliansen stödjer dock inte Mays lag. Alliansens riksdagsledamöter är de mest extrema (längre åt höger), inte partimedlemmarna som blott är aningen något åt höger jämfört med alliansväljarna. En bidragande orsak till avsaknaden till att mönstret som Mays lag stipulerar inte återfinns för Alliansen är att nästan en tredjedel av allianspartiernas medlemmar är centerpartister och att deras väljarkår vetter mot mitten på vänster-högerskalan, inte åt höger. Detta vägs upp av Moderaternas partimedlemmar som är de enda bland allianspartierna som uppvisar det mönster som Mays lag beskriver och placerar sig längst till höger. Resultat för Alliansens partimedlemmar blir ett genomsnitt på vänster-högerskalan som ligger nära deras väljare. Resultatet för Alliansen visar att det är skillnad mellan partidemokrati och representativ demokrati. ${ }^{3}$ Den förra baserar sig på mobilisering av en del medborgare som löser medlemsavgift i partierna, medan den senare baserar sig på den betydligt större andelen av medborgarna som röstar i allmänna val.

\section{Slutsatser}

Som samhällsvetenskaplig lag tycks Mays lag nått en varierad framgång. Det är långtifrån att partiernas väljare, partimedlemmar och riksdagsledamöter visar ett enhetligt mönster utifrån Mays lag - att partimedlemmar tenderar att vara mer ideologiskt extrema än vad som är fallet med partiernas respektive elit och väljare. Dessutom varierar uppslutningen över tid och mellan vilka partier som uppvisar ett mönster enligt Mays lag och vilka partier som inte gör det. Någon total motsats mellan representativ demokrati och partidemokrati har i detta avseende inte kunnat skönjas. Ofta hamnar partimedlemmarna ideologiskt mitt emellan väljare och riksdagsledamöter. Det är dock möjligt att något annat hade kunna framkomma om åsikter i sakfrågor, snarare än position på vänster-högerskalan, hade studerats.

År 2010 var partimedlemmarna för de rödgröna partierna mer extrema än deras riksdagsledamöter och väljare. För allianspartierna var resultatet år 2010 mer splittrat. Mönstret för Moderaterna stämde in på Mays lag, men inte mönstret för de resterande allianspartierna. Även när väljare, partimedlemmar och riksdagsledamöterna slås samman till de politiska blocken upprepas resultatet: Mönstret för De rödgröna stämmer in på Mays lag, men inte mönstret för Alliansen.

Mays lag var inte starkare innan partiernas stora medlemstapp började. Men rollerna var till stor del omvända. År 1985 visade två av tre borgerliga partier - de som senare kom 
att ingå i Alliansen - ett mönster som överensstämde med Mays lag, medan de socialistiska partierna - som senare skulle vara med och bilda De rödgröna - uppvisade ett mönster som inte stämde överens med Mays lag. I undersökningen 2010 var det tvärtom: de borgerliga partierna - undantaget Moderaterna - stämde inte längre in på Mays lag, medan vänstersidan hade övergått till att uppvisa ett mönster som stämde överens med Mays lag.

I undersökningen från 2010 stämde inte Sverigedemokraternas väljare, partimedlemmar och riksdagsledamöter in på Mays lag. Vad som undersökts i denna artikel är dock vänster-högerskalan. Måhända är denna inte det som främst intresserar Sverigedemokraterna, oavsett om de är väljare, partimedlemmar eller riksdagsledamöter. Istället för vänster-högerskalan - som har ett starkt fokus på statens roll i samhällsekonomin - kan en konkurrerande ideologisk dimension vara aktuell för detta parti. Partiets profilfråga rör invandring, vilket är en viktig fråga för libertärauktoritärskalan, där Sverigedemokraterna placerar sig närmare den auktoritära polen (Hagevi 2015).

Anledningen till att partieliten - i denna undersökning representerad av riksdagsledamöterna - enligt Mays lag ska gå mot mitten är för att de vill avspegla väljarnas åsikter för att bli omvalda. I de nu presenterade resultaten verkar denna strategi möta varierade framgång. De resultat som presenterats i denna studie pekar också mot något som May inte tänkte sig. De partier som inte stämmer överens med Mays lag tenderar väljarmässigt tjäna på det, tvärtemot vad May menade skulle vara fallet. År 1985 vann de socialistiska partierna riksdagsvalet och Socialdemokraterna regeringsmakten. Samtidigt uppvisar just de socialistiska partierna ett mönster som inte stämmer överens med Mays lag (dessutom står deras partimedlemmar ganska nära varandra på vänster-högerskalan). De borgerliga förlorarna uppvisar däremot det mönster som Mays lag stipulerar. År 2010 vann allianspartierna regeringsmakten (och ett ökat röststöd) trots att alla utom Moderaterna (som i och för sig är det centrala och överlägset största partiet i Alliansen) uppvisade ett annat mönster än vad som enligt Mays lag ska framkomma (och Alliansens partimedlemmar tenderade att placera sig relativt nära varandra på vänster-högerskalan). Mönstret på den rödgröna förlorarsidan överensstämde däremot med Mays lag (samtidigt som deras partimedlemmar stod ganska långt ifrån varandra på vänster-högerskalan). Kanske är det minst lika viktigt eller till och med viktigare att partieliten har med sig både partimedlemmar och väljare än att enbart partieliten agerar strategiskt och röstmaximerar på ett sätt som kan fostra missnöje bland partimedlemmarna? I så fall är harmoniseringen mellan representativ demokrati och intern partidemokrati en nyckel till framgång för partierna. 


\section{Noter}

${ }^{1}$ En med åsiktsöverensstämmelse konkurrerande tanke är att valda politiska representanter även vad gäller sociala egenskaper ska likna väljarna, så kallad social representativitet. Det betyder då att egenskaper som kön, klass, utbildning, etnisk identitet och andra egenskaper ska ha samma fördelning bland valda politiker som bland väljarna. För anhängare av social representativitet har detta ett egenvärde, medan anhängarna av åsiktsrepresentativitet endast ser ett värde med social representativitet i den mån den förbättrar åsiktsöverensstämmelsen mellan väljare och valda.

${ }^{2}$ May (1973:135) menar att hans lag främst ska appliceras på konkreta sakfrågor. Andra menar dock att vänster-högerskalan är en "super issue” som sammanfattar en rad ställningstaganden i olika sakfrågor (Inglehart and Klingeman 1976:244).

${ }^{3}$ Forskning om blockpolitik har visat att väljare inför val beaktar förväntade koalitioners politik när de röstar (Duch m.fl. 2010). Detta kan vara en förklaring till att till exempel borgerliga väljare röstar på Moderaterna istället för partier som står dem närmare i ideologiskt avseende.

\section{Referenser}

Brothén, Martin \& Mikael Gilljam (2006): ’Mellanvalsdemokrati”, i Hanna Bäck \& Mikael Gilljam, (red) Valets mekanismer. Malmö: Liber, s 193-216.

Dahl, Svend (2011): Efter folkrörelsepartiet - om aktivism och politisk kursomläggning i tre riksdagspartier. Stockholm: Stockholms universitet

Downs, Anthony (1957): An Economic Theory of Democracy. New York: Harper \& Row Publishers.

Duverger, Maurice (1954): Political Parties: Their Organization and Activity in the Modern State. London: Methuen \& CO.

Esaiasson Peter \& Sören Holmberg (1985): Riksdagsundersökningen 1985. Göteborg: Statsvetenskapliga institutionen, Göteborgs universitet.

Esaiasson Peter, Mikael Gilljam, Sören Holmberg \& Lena Wängnerud (2010): Riksdagsundersökningen 2010. Göteborg: Statsvetenskapliga institutionen, Göteborgs universitet.

Farell, David M. (2011): Electoral Systems: A Comparative Introduction. Basingstoke: Palgrave Macmillan.

Fransson, Sara (2010): Att följa piskan eller hjärtat?: Partisammanhållningens utveckling i riksdagen efterpersonvalsreformens tillkomst. Kandidatuppsats, Institutionen för samhällsvetenskap, Växjö universitet, Växjö.

Hagevi, Magnus (1998): Bakom riksdagens fasad. Göteborg: Akademiförlaget Corona.

Hagevi, Magnus (2000): "Parliamentary Party Groups in the Swedish Riksdag”, i Knut Heidar \& Ruud Koole, (red), Parliamentary Party Groups in European Democracies: Political parties behind closed doors. London: Routledge, s 145-160. 
Hagevi, Magnus (2011): “Ideologier och värden”, i Magnus Hagevi, (red), Den svenska väljaren. Umeå: Boréa, 147-163.

Hagevi, Magnus (2015): Den svenska väljaren 2014. Lund: Gleerups.

Holmberg, Sören \& Mikael Gilljam (1987): Väljare och val i Sverige. Stockholm: Bonniers.Inglehart, Ronald \& Hans-Dieter Klingeman (1976): ”Party identification, ideological preference and the left-right dimension among western mass publics", i Ian Budge, Ivor Crewe \& Dennis Farlie, (red), Party Identification and Beyond: Representations of Voting and Party Competition. London: John Wiley \& Sons, s 243-276.

Katz, Richard S. \& Mair, Peter (1995): "Changing Models of Party Organization and Party Democracy: The Emergence of the Cartel Party”, Party Politics 1(1):5-28

Katz, Richard S. \& Mair, Peter (2009): ’The Cartel Party Thesis: A Restatement”, Perspectives on Politics 7(4):753-766. http://dx.doi.org/ 10.1017/S1537592709991782

Kitschelt, Herbert (1989): “The Internal Politics of Parties: The Law of Curvilinear Disparity Revisited”, Political Studies, 37 (3):400-421.

May, John D. (1973): ”Opinion Structure of Political Parties: The Special Law of Curvilinear Disparity”, Political Studies, 21 (2):135-151.

McKenzie, Robert. (1982): "Power in the Labour Party: The Issue of Intra-Party Democracy”, i Dennis Kavanagh,(red), The Politics of the Labour Party. London: George Allen and Unwin, s 191-201.

Michels, Robert (1983 [1915]): Organisationer och demokrati: en sociologisk undersökning av de oligarkiska tendenserna i vår tids demokrati. Stockholm: Ratio.

Oscarsson, Henrik \& Sören Holmberg (2013): Nya svenska väljare. Stockholm: Norstedts juridik.

Norris, Pippa (1995): “May’s Law of Curvilinear Disparity Revisited: Leaders, Officers, Members and Voters in British Political Parties”, Party Politics, 1 (1):29-47.

Pitkin, Hanna Fenichel (1967): The Concept of Representation. Berkeley and Los Angeles: University of California Press.

Strøm, Kaare \& Torbjörn Bergman (2011): ”Parliamentary Democracies under Siege?”, i Kaare Strøm \& Torbjörn Bergman, (red), The Madisonian Turn: Political Parties and Parliamentary Democracy in Nordic Europe. Ann Arbor: The University of Michigan Press, s 3-34.

Westerståhl, Jörgen och Folke Johansson (1981): Medborgarna och kommunen, studier av medborgerlig aktivitet och representativ folkstyrelse: Rapport 5 från kommunaldemokratiska forskningsgruppen, Kommunaldemokratiska kommittén, DS KN 1981:12. Stockholm: LiberFörlag/Allmänna förlaget.

Widfeldt, Anders (1999): "Losing Touch? The Political Representativeness of Swedish Parties, 1985-1994”, Scandinavian Political Studies, 22 (4):307-326. 